\title{
Transhumant Goat and Sheep Husbandry Practices in High Hills of Annapurna Conservation Area
}

\author{
Anish Sapkota ${ }^{1}$, Biplov Sapkota ${ }^{2}$, Suwash Khatiwada ${ }^{3}$, Grishma Neupane $^{4}$
}

\author{
${ }^{1,2,3}$ Agriculture and Forestry University, Chitwan, Nepal \\ ${ }^{4}$ Ministry of Land Management, Agriculture and Cooperatives, Gandaki Province, Nepal
}

\begin{abstract}
Small ruminants are the most reliable source of meat in Nepal. However, national production is still insufficient to fulfill their demand. Transhumance pastoralism is a migration system in which farmers graze their animals in mountain pastures in warm seasons and lower altitude forests during colder seasons. Yak, sheep and Goat are reared under this system in Himalayas of Nepal. Farmers travelling through in Madi, Seti, Mardi and Modikhola basin follow transhumance system including Baruwal Sheep and Sinhal goat. A study was conducted to understand small ruminant husbandry system used by transhumant farmers. Farmers of 4 different locations were interviewed and focus group discussion was performed with inhabitants of nearby villages. Additional information were collected from ACAP and VHLSEC. Results revealed that number of transhumant farmers is decreasing. Migration pattern is determined by season (temperature, humidity, rainfall) and fodder availability in the region. This pattern was refined during centuries of practice. Mixed grazing by sheep and goat is beneficial since they feed on different type of pasture. Farmers are slowly adopting veterinary practices. However, treatment depends on value of animal. Animals except newborn lambs are kept open during night and protected by Tibetan mastiff dogs. Availability of better opportunities and decreasing market value of wool are two major constraints faced by farmers. As conclusion, transhumant farming system as present in the study region is an efficient way to exploit seasonally barren landscape to produce meat animals. This way of production can be applied to elevate lifestyle of people living in those landscapes.
\end{abstract}

Keywords-Annapurna Conservation Area, , Husbandry Practices, Small ruminants, Transhumance.

\section{INTRODUCTION}

Regular movement of herds between specific locations to use up seasonally available pastures is termed as pastoralism (Blench, 2001). Unlike nomads, movement of transhumant farmers throughout the year, are limited within a short territory. The movement is based on livestock productivity, markets, rangeland conditions and climate change (Aryal et. al, 2014). They normally shift from highland to lowland during the winter months in order to protect from the severe cold and snowfall (Pandey \& Chhetri, 2005; Aryal et. al, 2014). This form of pastoralism is one of the ancient ways of livestock farming existing in Tibetan plateau of south west Asia (Ekvall, 1968).

Data from FAO (2017) mentions 1.2 billion sheep and 1.03 billion goats worldwide. Goat has been one of the most accepted and easily available meat-purpose domestic animals in Nepal. Goats are also the most populous animal in the nation, having a population of 11.16 million (DLS, 2018). Every year, 67,706 metric ton goat meat is produced in Nepal (DLS, 2018). However, this amount of goat meat is not sufficient to meet the national demand for goat meat, and therefore more than 60 million Nepali rupees worth of lice goats are imported annually in Nepal. Similarly, sheep is also one of the most accepted meat species. Wool is another valuable product available from sheep. Total sheep population in the nation is 0.8 million. Though this figure seems low as compared to goats and other animals, there is great potential for sheep keeping due to relatively infrequent problems in marketing.

Though transhumant way of pastoralism is as old as domestication of livestock and is the earliest form of livestock husbandry, there is no history of pastoralism 
older than 4 centuries in Tibet (Miller, 2007). From Tibet, pastoralism reached Nepal along with migration of Mongol community from Tibet. Chauri, sheep and goats are major livestock species reared under the transhumance system in the region. Normally, yaks are kept free in the high pasturelands whereas goats/sheep are driven out to graze during the day in the pastures and taken back around the tent-house during the night. They normally use horses and guard dogs while shepherding (Pandey \& Chhetri, 2005).

Annapurna Conservation Area, Nepal's largest protected area, lies in Annapurna range of the Himalayas. Elevation of the conservation area ranges from 790 meter in the lowest to Annapurna I 8091 meter in the highest point. The conservation area stretches across Manang, Mustang, Kaski, Myagdi, and Lamjung Districts and includes foothills of Himalaya to snowcapped mountains and trans Himalayan steppes. The himalayan foothills comprises the southward part of the conservation area and are considered as valuable ecological as well as cultural hub. These hills are principally populated with Gurung-ethnic communities with intermixed Brahmin, Chhetri and Dalits ethnic communities on lower altitude. Seti, Madi, Mardi and Modikhola are major rivers of the region (ACAP, 2019).

Annapurna Conservation Area is the first protected area conserving natural heritage as well as cultural heritage. This is possible by allowing local resident to live within the boundaries as well as own their private property and maintain their traditional rights and access to the use of natural resources (ACAP, 2019). Livestock is an inseparable part of agriculture in the whole region and is even more important on the high hills where temperature, soil humidity and nutrient content doesn't support crop production. For more than six months every year, snowfall occurs and covers all habitable areas thus making the major parts of the upper region unsuitable for both humans and livestock. For these reasons, farmers have to move towards lower altitude areas in search of warmer lands with plenty of pastures and forests.

Most of the land in high hills and trans himalayan region is not suitable for resident agriculture and livestock rearing. In low producing lands like these, transhumant pastoralism is the most efficient way of land utilization. This way of pastoralism allows growth of lowland pasture during summer which acts as reserve food for animals during winter. Alpine pastures, which grow only during summer are also duly utilized. In this way, pastoralists can get maximum benefit from the system. Although transhumant farmers contribute a great role in ecology of mountainous regions, the methodologies they use for farming and their contribution has yet to be established. Transhumant farmers living high in the Himalayas are away from reach ISSN: 2456-1878 of government supports and services. There is no data on the population of these farmers and their animals. Use of local farming practices used by farmers has yet to be understood. The number of farmers is on a decreasing trend. This main objective of this study is to understand the small ruminant husbandry system used by transhumant farmers in the region and thereby fulfill the existing knowledge gap on the subject.

\section{MATERIALS AND METHODS}

Taking into consideration the common principles of rapid rural appraisal (Chambers, 1994), a three-step procedure was formulated and implemented to collect the information related to transhumant goats and sheep in the high hills of Annapurna Conservation Area.

\section{A. Collection of information of small ruminant herding villages:}

On the basis of information provided by Veterinary Hospital and Livestock Service Expert Center, Gandaki Province and Annapurna Conservation Area Project Headquarters located at Pokhara, the goat and sheep herding communities around the ACA were identified in Seti, Madi, Mardi and Modikhola basin. The transhumance sheep herding communities of Mirsa, Sikles, Riwan and Dhampus area were selected for this case study. Four flocks were chosen from the herders, each from Mirsa, Sikles, Riwan and Dhampus villages.

Focus group discussion (FGD):

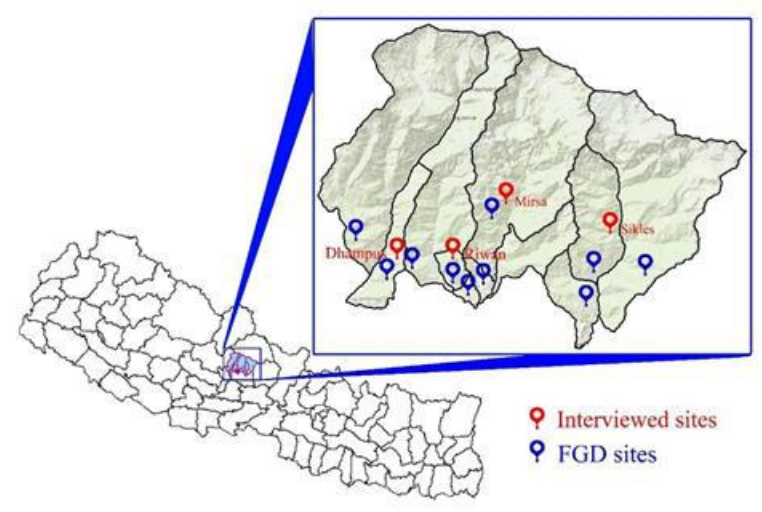

Upon discussion with Veterinary Hospital and Livestock Service Expert Center and Annapurna Conservation Area Project officials and four key informants each from the villages in the study area, a checklist was prepared to gather information on general details of farm and farmers, management and nutritional practices, reproductive and production parameters, herd health management, migration pattern, and problems faced by the farmers. 
Later, a pre-planned and organized discussion was organized with villagers, following the steps of rapid rural appraisal. 4 key informants from different villages, selected on the basis of experience, were interviewed about transhumance migration, animal management, productivity and the current situation of transhumant sheep and goat farming.

The participants in the FGD were the local farmers and former transhumant goat and sheep herders. The FGD was organized in each of the four villages of interest, where at least 10 farmers were present during the session. The discussion was set according to the checklist. Information collected during FGD were further verified with key informants' so as to ensure the reliability of information obtained, when further discussion with the shepherds during field visits who were with the animals on the pasturelands was performed.

\section{B. Field visit}

The information collected during FGD and key informants' interviews were further confirmed with the 4 shepherds in the field who were migrating the flocks. Questions in relation to the livelihood and traditional migratory goat and sheep herding were further discussed in depth with the shepherds.

\section{Sample Population:}

In this study, survey was performed among transhumant farmers on Seti and Madi river basin as well as other transhumant farmers who utilized Mardi and Modikhola basin during winter.

\section{Data collection}

Data collection was performed by a semi structured questionnaire survey with transhumant farmers. Questions regarding different aspects of farming were asked with farmers and their problems were listened properly. Questions included Migration pattern, General details of farm and farmers, Management of the farm, Nutrition, reproductive and production parameters of the animals, Herd health management, Breeding, and problems faced by the farmers.

Before collection of data, general knowledge on farmers was gained from Veterinary Hospital and Livestock service expert center, Kaski and Annapurna Conservation Area Project Headquarter, Kaski. This was followed by visiting resident farmers of different regions on Seti, Madi, Mardi and Modikhola basin. The information on contemporary location of herd, thus gained, led to individual meeting with herder. After interview with herders, the data was validated by focal group discussion among resident farmers from nearby villages.

\section{E. Data summarization}

Knowledge obtained from the interview with farmers was summarized into report. Information from each of the farmers was summarized qualitatively and quantitatively followed by detail study on the matter. Additional information was $\mathrm{n}$ gathered from literature review on forage availability of forage and other aspects that were described by farmers in layman term. Altitude of different locations was obtained from Annapurna Conservation Area Project Headquarter.

\section{RESULTS AND DISCUSSION}

\section{A. History and present context:}

Two decades before today, there were many farmers practicing transhumance system in this region. There were more than 10 farming groups each in Lahachok, Ghachok, Tuse, Mirsa, Sikles, Mise, Argui, Tangtin, Dhampus, Chipli and Ghamrung. Among them, most of the farmers have left this practice. Now, there are a few sheep herds based on ghandruk, one each based on Mirsa, Sikles and Tangtin. Interviewed old herders mentioned that there used to be a practice of keeping small sheep herds (around 100) by each farmer and many farmers used to combine their stock to make bigger herd. But this trend is also losing popularity with time, and now a single herd owner keeps big herds with many hired herders working for the herd. this trend is more common in Seti and Madi basin. however, combined herds are also common among farmers who utilize pastureland and forests on Mardi and Modikhola basin during winter.

\section{B. Breeds and breeding:}

The breeds of goat and sheep kept by farmers of the region are of local breeds. Breed of the goat is Sinhal and sheep is Baruwal $(n=4)$. These animals are highly adapted to the environment and migration pattern used by farmers. Source of buck/ram is mostly from own farm, selected on the basis of physical parameters and libido.

\section{Migration pattern:}

The migration system followed by farmers of high hills in Annapurna conservation area, south to Annapurna and Dhaulagiri Range is termed as transhumance since they have definite settled land where they reside like non pastoral society and the route used during migration is fixed. The route of migration depends on season (temperature, humidity, rainfall) and fodder availability in the region and has been refined during hundreds of years of practice. During summer, farmers move their stock up towards the naked hills and the region that are covered with snow whole year. As temperature starts to decline, 
their herd start to come downward, through naked hills, towards the land covered by forest and vines.

\section{Flock structure and grazing:}

All of the interviewed farmers followed mixed practice of keeping both goat and sheep, in the same herd. Keeping both goats and sheep is especially beneficial since they can be grazed at the same time. Among them, goat is a selective feeder and sheep is non selective feeder. When left to graze in the same pasture, goats browse the top nutritious part of the pasture. Sheep flocks graze the whole tiller, even uprooting them. In this way, the hill is left naked at the end of grazing by these two species. In turn, animals defecate and urinate in the pasture, hereby returning some part of nutrients back to soil.

Table.1: Altitude and fodder availability

\begin{tabular}{|l|l|l|l|}
\hline $\begin{array}{l}\text { Altitude } \\
\text { (Masl) }\end{array}$ & \multicolumn{2}{|l|}{ Season(s) } & Pasture type \\
\hline $4000-4500$ & \multicolumn{2}{|l|}{ Mid to late summer } & Alpine rangeland \\
\hline $3000-4000$ & $\begin{array}{l}\text { Early } \\
\text { summer }\end{array}$ & $\begin{array}{l}\text { Late } \\
\text { summer }\end{array}$ & $\begin{array}{l}\text { Sub-alpine } \\
\text { rangeland }\end{array}$ \\
\hline $2000-3000$ & $\begin{array}{l}\text { Mid to late } \\
\text { spring }\end{array}$ & Autumn & $\begin{array}{l}\text { Forest } \\
\text { temperate } \\
\text { rangeland }\end{array}$ \\
\hline $1200-2000$ & \multicolumn{2}{|l|}{ Winter and early spring } & Forest and villages \\
\hline
\end{tabular}

The pasture above 4000 meters above sea level, are of alpine type, covered by snow during winter. When snow melts on spring, grasses grow very quickly and provide nutritious grass to the herd during summer months. The stocks are maintained in this type of forage for few weeks in summer, depending upon herbage availability and environmental temperature. While descending downward during September and October, herd reaches sub alpine grasslands at elevation of 3000 to 4000 meters. Herd stays few weeks in this type of grasslands and then move to temperate grasslands and forests at 2000 to 3000 meters nearby human settlements. After spending few weeks in forests, herds mostly come to valley and lowland villages during late autumn and winter. In villages, herd feeds on aftermath in the rice-field and also graze on nearby forest. Resident farmers in these villages allow herders to stay and graze large herds on their land. Resident farmers also give food to the herders as well as herding dogs. Once winter is about to over, herd starts to move upwards, following almost same route. During spring and summer, animals graze on newly grown pasture and hence nutritional status of herd is best at this stage. However, there is no system of providing concentrate ration to animals except salt and mustard cake due to remoteness of the grazing lands and unavailability of transportation facility.

Farmers mentioned that 'Toxic plants' is not a common problem among the farmers when the herd is in villages and forests of valley and lowland $(n=3)$. However, on the alpine grassland and naked hills on the base of mountains, farmers are facing problems due to toxic plant marsh marigold (Caltha palustris). According to farmers, they are using traditional practice to face this problem as well. They use lemon concentrate to treat this condition $(n=4)$.

\section{E. Veterinary practice:}

Farmers, though being migratory in nature and working in one of the most difficult landscapes in the world, are not away from practice and knowledge from the outside world. They are adopting modern veterinary practices slowly and adapting their way of life accordingly. Practices such as vaccination, deworming, and treatment of some disease are in practice. Government officials and veterinary technicians from Livestock Service Center visits farm in the month of April-May to vaccinate against Peste des Petits Ruminants. Deworming practice is regular on half yearly basis on February-March and September-October among farmers of Mirsa and Sikles. However, deworming is not common among farmers of other regions $(n=2)$. Among ectoparasites, Tick, Mange and Nasal leech are the most common. Ivermectin is used as control measure against mange. Traditional medication is practiced to treat most of the disease and management of physical injury. Major health problems encountered in the region includes Fractures, cold stress and pneumonia. Farmers mentioned that treatment also depends on value of the animal. If an animal is young and productive, it is treated. Treatment is not practiced for old or less productive animals.

\section{F. Housing:}

Transhumant animals are highly adapted to harsh climate of the ecological region and can withstand environmental extremes. These animals are kept under the sky whole year irrespective of cold, rain or snowfall occurring in the region. During night, herders stay in the tent made up of polythene in the forest or pastureland and gather animals around the tent. There is a group of trained Tibetan mastiff dogs to take care of this herd and save from predators. According to farmers, most common predators in the region includes Leopard in the forest and snow leopard on the naked hills. However, predation is not a big issue for farmers, as they have trained dogs to guard the flock $(n=4)$.

\section{G. Other managemental aspects:}

There is a ram per 50-100 ewes and similar ratio is followed for bucks and does. In case of sheep, mating takes 
place on random basis and breeding season starts from the month of May. Peak breeding season is on June to July. After 5 months of gestation, lambing season starts from mid-September and lasts till early January $(n=4)$. even after this season, small number of ewes become pregnant and lambing occurs throughout the year. Newborn lambs are kept on special shed nearby the tent and dam is allowed to graze with the flock. Lambs get mothers milk only twice a day. Once lambs start eating grass, they are mixed to the herd. Weaning happens naturally once Ram starts to chase ewe for mating and it happens around 3-6 months after lambing. Castration of male lambs is done using burdizzo castrator on 5 months to one year of age. There is no special procedure for fattening of lambs before being sold. Main season for selling of livestock is during festivals. Rams and bucks are sold for festivals and rituals of different ethnic groups. Wethers are sold for meat and demand rises during Dashain. Some of the kids and lambs are sold even before castration is done. Among lambs and kids kept for replacement flock, puberty commences at the age of 1.5-2 years in case of ewes and does and 6-8 months in case of bucks and rams. However, young bucks do not get chances to mate due to dominance of older bucks. $(n=3)$

Shearing is done on half yearly basis, around march and September. Farmers use this hair on traditional way to make clothes such as kambal and bakhkhu. Excess wool is sold to nearby villages and occasionally reach market level.

When reproductive performance of animal decreases below expected level, there is no practice of treatment and management of the conditions. Instead, culling is common practice in this situation. An ewe/doe fails to breed during one season, it is not waited for it to breed during next season. Instead, it is culled $(n=4)$. Normally, ewes and does are kept for ten to twelve parturitions and then culled. Instead, bucks are kept with the herd till their productivity is at peak and then culled. Since animals are culled at higher rate, replacement herd are also made at higher rate.

\section{H. Constraints}

There has been a noticeable decline in the number of livestock rearing households and herder population in the past years. There are many problems behind the decline, of which some are listed as follows:

\section{1) Availability of better opportunities}

The reason behind this drastic change in culture and unavailability of labor forces, according to farmers, is employment opportunity. Even after working their entire lives, the don't consider themselves able to provide a better life for their children. Due to low income and lack of assurance of profit in this business, there is trend of ISSN: 2456-1878 decreasing attraction to this way of livelihood. This form of pastoralism is also suffering from lack of herders. Similarly, there has been an abrupt decline in people wanting to be herders. In the past, people agreed to be a herder for an exchange of one ram every year. But at present, the rate of payment being practiced in the region is Rs. 15000 on a monthly basis plus food and accommodation on tent. Despite this, it still is not possible to find herders. The livestock owners preferred old herders as compared to new ones since new herders do not have traditional knowledge and practice that was transferred from previous generation.

\section{2) Decreasing market value of wool:}

Farmers mentioned that there used to be great market of wool in the past days. But now, this market is drastically reduced. According to farmers, main reason behind this decline is availability of other sources of fiber and already decreasing trend of transhumance pastoralism. There used to be wool traders who come to buy wool at the pasture itself. Since transhumant pattern was already decreasing, it was no more profitable for the traders to travel through Himalayas and collect wool from sparsely distributed farmers. With declining market, price of wool is also decreasing. It used to cost around 80 per $\mathrm{kg}$ in the past, which has declined to around Rs. 30 per kg now-days. At present, most of the wool remains unsold and is thrown after shearing.

\section{DISCUSSION}

Transhumance based on sheep and goat is one of the most common form of pastoralism in the Himalayan region, other being based on Yaks and Chauri (Ekvall, 1968). The breed used by farmers of the region were Baruwal sheep and Sinhal goat. These breeds are common in the southern part of Himalaya Mountain range (Neupane, 2016; Shrestha, 1997). Decreasing trend of transhumant sheep and goat herding is justified further by Banjade\&Paudel (2008). Decreasing national population of sheep also suggests this trend (DLS, 2018). Pattern of upward and downward migration is similar to that mentioned by (Neupane, 2016) The system of forage only ration for most of the animals is adapted by most of the transhumant sheep and goat farmers in the region (Singh et. al., 2006; Tiwari et.al., 2007).

The major constraints mentioned by farmers were Shepherding problem and decreased market value of wool. Shepherding problem was also mentioned by Pandey \&Gyawali (2012), in the way similar to mentioned in this article. Problems related to marketing was also mentioned by Tiwari et.al. (2007) and Pandey \&Gyawali (2012), 
though the problems he mentioned were mainly focused on marketing of other products as well as wool. Surveyed farmers had clearly mentioned that marketing of other products is not a constraint in the region. Other constraints as mentioned in other literatures include poisonous plants (Pandey \&Gyawali, 2012), shrinking pastureland (Banjade\&Paudel, 2008), Restriction in transboundary movement to Tibet (Tiwari et al, 2007), which were not considered as priority by interviewed farmers.

\section{CONCLUSION AND RECOMMENDATION}

Transhumance system as present in high hills of Annapurna Conservation Area is developed through centuries in order to maximize utilization of available resources in agriculturally unsuitable zone of the region. This study concludes that the number of farmers involved in transhumant farming is in decreasing order. Most of the ancient routes that have been used in the past are now abandoned. Migration pattern is driven by two factors: temperature and forage availability. Use of mixed herd of goat and sheep has ensured maximum utilization of forage in the pasture. Adaptation in high altitude and low temperature is attributable to local breeds. Farmers are slowly adopting veterinary practice but housing and feeding practices remain unchanged. There is no breeding strategy and it occurs randomly within the herd. Labor force required for transhumant system is slowly migrating in search of better opportunities. As a result, farmers cannot find herders to take care of the herd. Another constraint among the farmers is decreasing value of wool.

Transhumant farmers are most important source of meat for the country and the number of farmers is decreasing. Government should assure farmers that there is a good profit in this business. This can be done by providing loans and subsidies for farmers to start or expand the business. Similarly, availability and cost of veterinary service should be brought to farmers' access. Scientific pasture management can be practiced in the barren lands in order to ensure good nutrition and health of the herd. Experts from government should also support farmers in this purpose. Farmers from two or more villages are found to be clustered in the same location, hereby over utilizing pasture. Farmers can make good contact with each other, and work together to ensure that their herd are not at same location at same time. Annapurna Conservation Area Project can play a role in this. Nutrition status of animals can be improved by using concentrate feed in ration. This will result in increased profitability of the business. Market of wool can be created by providing wool processing and knitting trainings to farmers family. This has to be done by government as well as farmers level.

\section{REFERENCES}

[1] Annapurna conservation area project. (2019, April 19). Annapurna conservation area project . Retrieved from National Trust for Nature Conservation: https://ntnc.org.np/project/annapurna-conservation-areaproject-acap

[2] Aryal, S., Maraseni, T. N., \& Cockfield, G. (2014). Sustainability of transhumance grazing systems under socio economic threats in Langtang, Nepal. Journal of mountain science, 1023-1024.

[3] Banjade, M. R., \&Paudel, N. S. (2008). Mobile pastoralism in crisis: Challenges, conflicts and status of pasture tenure in Nepali mountains. Journal of Forest and Livelihood, 49-57.

[4] Blench, R. (2001). Pastoralism in new millinium. Kathmandu: Overseas Devlopment Institute.

[5] Chambers, R. (1994). The origins and practice of participatory rural appraisal. World development, 22(7), 953-969.

[6] Department of livestock Services. (2018). Livestock Statistics fo Nepal. Lalitpur, Nepal: Department of livestock services.

[7] Ekvall, R. B. (1968). Fields on the hoof Nexus of tibetan nomadic pastoralism. New York: Holt, Rinehart and winston.

[8] FAO. (2017). FAOstat. Retrieved 4 2, 2019, from FAO: http://www.fao.org/faostat/

[9] Miller, D. J. (2007). The World of Tibetan Nomads. In D. J. Miller, Nomads of Tibetan Plateu and Himalaya.

[10] Neupane, G. (2016). Effect of altitude, season and pasture quality on blood parameters of range fed baruwal sheep under transhumance system. Chitwan: Agriculture and Forestry University.

[11] Pandey, L. N., \&Gyawali, R. (2012). Constraints and potential of goat and sheep production under transhumance management system in the high mountainous regions of nepal. Research and Development Strategies for Goat Enterprises in Nepal. Kathmandu: NARC.

[12] Pandey, M. R., \& Chhetri, M. (2005). Nomads and pastoralism: Linkage with biodiversity conservation in upper Mustang, Nepal. Our Nature, 42-49.

[13] Shrestha, N. P. (1997). Productive performance of transhumant sheep and goats at Guphapokhari site. Kathmandu: Pakhribas Agricultural Center, Dhankuta.

[14] Singh, D. R., Kaul, S., \&Sivaramane, N. (2006). Migratory Sheep and Goat Production System: The Mainstay of Tribal Hill Economy in Himachal Pradesh. Agricultural economics research review, 387-398.

[15] Tiwari, M. R., Chapagain, P., Basnet, R., \& Kusum, N. (2007). Bhyanglung sheep production system in Manang and Mustang district of western Nepal. Proceedings of the 7th national workshop on livestock and fisheries research, 2007 (pp. 157-164). Lumle, Kaski: Regional agriculture research center, lumle, kaski. 